\title{
Mitral Valve Prolapse In Patients With Benign Joint Hypermobility Syndrome (BJHS)
}

*Tariq Jassim Mohammed, M.B.Ch.B, DRMR

\begin{abstract}
Background: Joint hypermobility was first mentioned by Hippocrates as an isolated feature, when he described the Celts' Incapacity to Pull a Bowstring or Throw a Dart, Due to The Slackness of Their Limbs

Objective: to determine the prevalence of mitral valve prolapse(MVP)in patients with benign hypermobility syndrome (BJHS).

Type of the study: Cross -sectional study.

Methods: Ninety patients with BJHS were included in this study. Full cardiological assessment was done for all of them, which include clinical examination, electrocardiography and echocardiography. Cardiac assessment was done for another sixty age and sex matched (normal mobile) Individuals served as a control group. Statistical analysis was done by using $T$ test or chi square as indicated.
\end{abstract}

Results: Among 90 patients with BJHS, MVP was reported in 26 patients $(28.9 \%)$ compared to four individuals $(6.7 \%)$ of the control group on modern echocardiography studies $(P=0.013)$.

Conclusions: the prevalence of MVP was significantly higher among patients with BJHS compared to normal mobile individuals.

Key Words: Mitral valve prolapse, Benign hypermobility syndrome

Al-Kindy College Medical Journal 2017: Vol.13 No.1 Page: 8-10

* Baghdad Al-Karkh General Hospital

Received $15^{\text {th }}$ Feb 2017, accepted in final $30^{\text {th }}$ March 2017

Corresponding to Dr Tariq Jassim Mohammed M.B.Ch.B, DRMR email:tariqaljupory@yahoo.com oint hypermobility (JH) was first mentioned by Hippocrates as an isolated feature, when he described the Celts' Incapacity to Pull a Bowstring or Throw a Dart, Due to The Slackness of Their Limbs (1). Hypermobility Syndrome Is Commonly Occurring and Frequently Overlooked Entity, Which Causes Much Suffering in The Community (2). JH Arouse Great Interest in The Last Decades for Being Associated to Musculoskeletal Dysfunctions, As Well As Abnormalities in Several Organic Systems and Among Them, The Mitral Valve Prolapse (MVP) (3).

Joint Hypermobility $(\mathrm{JH})$ Is Defined As The Capacity To Perform Articular Movement With Higher Range Of Motion The Normal One(4)(5).Its Prevalence Depend On The Characteristics Of The Studied Group Determined ,Among Others, By Age ,Sex, Ethnicity And Genetic Factors That Have An Effect On The Process Of Movement Evolutions. Studies Have Stated That Female Individuals Have A Higher Joint Mobility Than Male Individuals And That It Decreases With Age (6)(7).Approximately $30 \%$ Of The Adult Individuals Are Considered As Presenting $\mathrm{JH}(8)$. The Feature of $\mathrm{JH}$ That Appear in Some Hereditary Disease Such as Marfan Syndrome, Osteogegesis Imperfecta, Achard Syndrome, Homocystinuria And Hyperlysinemia Must Be Differentiated from Those Present in Normal Population.

$\mathrm{JH}$ in the general population is a common condition and a genetically determined one (8). There is a new consensus that the Benign Joint Hypermobility Syndrome (BJHS) is a multisystemic disorder, of which characteristics coincide with the characteristics of the hereditary disorders of the connective tissue, which include Marfan syndrome, Ehlers-Danlos syndrome and Osteogenesis Imperfecta(9).

The MVP is a common cardiovascular disorder, with a strong hereditary component, generally diagnosed in young individuals (10). Mitral valve prolapse was reported during clinical practice in patients with various heritable disorder of connective tissue such as Ehlersdanlose syndrome (12), Marfan's syndrome (13), and Osteogenesis imperfecta (14).

There were conflicting report regarding the association between BJHS and MVP. Some reports show increase incidence $(14,15,16,17)$, and other challenged this association and show no difference between the incidence of MVP in BJHS and normal mobile subjects $(18,19)$.

Methods: Ninety patients with joint hypermobility were included in this cross-sectional study.

All patients were evaluated for cardiac and respiratory symptoms and signs. Full cardiological evaluation was done blindly by another physician in all patients, which include clinical examination, electrocardiography and echocardiography, which was performed by using twodimension voluson 5300 D-Kretz technik -S-PPA2-4 with a $2.5 \mathrm{MHz}$ probe.

During examination, particular attention was paid to the presence or absence of echocardiographic evidence of MVP according to the echocardiographic diagnostic criteria of MVP by Perloff et al (20), Cardiac assessment was done for another sixty age and sex matched (normal mobile) individuals served as a control group.

Statistical analysis, the T-test was used for mean age and chi-square for other variable correlation.

Results: All the 90 hypermobile patients (75 females and15 males), age range from 11 to 40 years with a mean of 22.68+_5.69 and 60 normal mobile individuals (50 females and 10 males). The demographic finding of patients with BJHS and controls are shown in table (1). Among the hypermobile group, mitral valve prolapse was diagnosed in 26 patients ( 4 males and 22 females), two of them with mild mitral regurgitation, 5 patients had murmurs on auscultation and another six with mid systolic click. Four individuals of the control group had 
mitral valve prolapse $(6.7 \%)$ on echocardiography. So, MVP was reported significantly higher among patients with BJHS compared to the control group $(P=0.013)$.

Table (1): Demographic findings of 90 patients with BJHS and 60 controls.

\begin{tabular}{|c|c|c|}
\hline Findings & Patients & Control \\
\hline Mean age & $\begin{array}{c}22.68 \pm 56.9(11-40) \\
\text { year }\end{array}$ & $\begin{array}{c}22.17 \pm 4.98(11-40) \\
\text { year }\end{array}$ \\
\hline Sex: Female & 75 & 50 \\
\hline Male & 15 & 10 \\
\hline $\begin{array}{c}\text { Beighton } \\
\text { score }\end{array}$ & & \\
\hline $0-3$ & 0 & 60 \\
\hline 4 & 13 & 0 \\
\hline $5-6$ & 51 & 0 \\
\hline $7-9$ & 26 & 0 \\
\hline $\begin{array}{c}\text { Mean } \\
\text { Beighton } \\
\text { score }\end{array}$ & 5 & 1 \\
\hline
\end{tabular}

Beighton score of $\geq 4 / 9$ were reported among all the hypermobile group, and 54 patients $(60 \%)$ had arthralgia for $>3$ months in more than four joints, 15 of them had MVP $(57.7 \%)$, while 23 patients $(25.6 \%)$ had arthralgia in 1-3 joints; 9 of them with MVP (34.6\%).

Marfanoid habitus was reported in 20 patients $(22.2 \%)$, six of them was with MVP. Only 12 patients (13.3\%) had past or present history of dislocation with three of them had MVP. Soft tissue rheumatism was reported in 8 patients $(8.9 \%)$ and only 2 of them showed MVP.

Asthma and wheezy chest was reported only in 4 patients $(4.4 \%)$, one of them only had MVP as shown in table (2).

Table (2): the correlation between various clinical findings and MVP in 90 patients with BJHS.

\begin{tabular}{|c|c|c|c|c|}
\hline $\begin{array}{c}\text { Clinical } \\
\text { feature }\end{array}$ & $\begin{array}{c}\text { No. of } \\
\text { patients }\end{array}$ & $\%$ & $\begin{array}{c}\text { No. of } \\
\text { patients } \\
\text { with } \\
\text { MVP }\end{array}$ & $\begin{array}{c}\text { PERCENT of } \\
\text { clinical feature } \\
\text { in patient with } \\
\text { MVP }\end{array}$ \\
\hline $\begin{array}{c}\text { Joint } \\
\text { mobility } \\
\text { score } \geq 4\end{array}$ & 90 & 100 & 26 & 100 \\
\hline $\begin{array}{c}\text { Arthralgia } \\
\geq 4 \text { joints }\end{array}$ & 54 & 60 & 15 & 57.7 \\
\hline $\begin{array}{c}\text { Arthralgia } \\
\text { 1-3joints }\end{array}$ & 23 & 25.6 & 9 & 34.6 \\
\hline $\begin{array}{c}\text { History of } \\
\text { dislocation }\end{array}$ & 12 & 13.3 & 3 & 11.5 \\
\hline $\begin{array}{c}\text { Soft tissue } \\
\text { rheumatis } \\
\text { m }\end{array}$ & 8 & 8.9 & 2 & 7.7 \\
\hline $\begin{array}{c}\text { Marfanoid } \\
\text { habitus }\end{array}$ & 19 & 21.1 & 6 & 23.1 \\
\hline $\begin{array}{c}\text { Asthma \& } \\
\text { wheezy } \\
\text { chest }\end{array}$ & 4 & 4.4 & 1 & 3.8 \\
\hline
\end{tabular}

Discussion: In this study, MVP was reported in $28.9 \%$ of hypermobile patients and $6.8 \%$ of controls $(P=0.013)$. We have concentrated on the incidence of MVP. There were conflicting reports on the association between BJHS and MVP in various studies from different ethnic groups. MVP was considered in the 1980s to be feature of hypermobile, but this was questioned in the 1990s on using modern echocardiography technology and criteria. Graham, 1981(14), Pitcher,1982(15), Handler,1985(21), and Ondrasik,1988(22), all described an increase prevalence of MVP in individuals with joint hypermobility or vice versa. Other studies by Jessee,1980(18) and Marks, 1983(23) challenged this association and conclude in their studies that those patients with MVP do not have generalized joint laxity.

Mishra et al,1996(19) who used modern echocardiographic technique and strict criteria showed no evidence of increase of MVP among 58 hypermobile subjects compared with 30 normal mobile age and sex matched control.

There was a report from Venezuela by Riana et al,2001(24) and although they used the Beighton 9 score criteria and not the new set of criteria for BJHS. There was no mention of the type of echocardiogram used in the study, yet they have concluded that among extra-articular manifestations, MVP was commonest one.

Conclusion: The prevalence of MVP was significantly higher among our patients with BJHS compared to normal mobile individuals.

\section{References:}

1. Egri D, Yoshinari NH. Hipermobilidade articular generalizada. Rev Bras Reumatol. 1999; 39 (4): 231-6.

2.Grahame R. Hypermobility Syndrome. Rheumatology in Europe 1996;25/4:124-7.

3. Araújo CGS, Chaves CPG. Adult women with mitral valve prolapse are more flexibe. Br J Sports Med. 2005; 39: $720-4$

4. Lamari NM, Chueire AG, Cordeiro JA. Analysis of joint mobility patterns among preschool children. Sao Paulo Med J. 2005; 123(3): 119-23.

5. Malfait F, Hakim AJ, De Paepe A, Grahame R. The genetic basis of the joint hypermobility syndromes. Rheumatology. 2006; 45: 502-7.

6._Cavenaghi S, Folchine AER, Marino LHC, Lamari NM. Prevalência de hipermobilidade articular e sintomas álgicos em trabalhadores industriais. Arq ciênc saúde. 2006; 13 (2): 66-70.

7._Lamari NM, Marino LC, Cordeiro JA, Pellegrini AM. Flexibilidade anterior do tronco adolecente após o pico da velocidade de crescimento em estatura. Acta Ortop Bras. 2007; 15 (1): 25-29.

8. Hakim AJ, Cherkas LF, Grahame R, Spector TD, Macgregor A. The genetic epidemiology of joint hypermobility. Arthritis Rheumatism. 2004; 50 (8): 26404.

9. Grahame R. Joint hypermobility and genetic collagen disorders: are they related? Arch Dis Child. 1999; 80: 188-91.

10. Levine RA, Slaugenhaupt SA. Molecular genetics of mitral valve prolapse. Curr Opin Cardiol. 2007; 22 (3): 171-5.

11. Brandt KD, Sumner RD, Ryan TJ, Cohen AS. Herniation of Mitral valve leaflets in the Ehlers-Danlose syndrome. Am J cardiol 1975; 36:524-

12. Brown OR, Demots $H$, Kloster JE, Roberts $A$ ,Menasthe VD, Beals RK. Aortic root dilation and Mitral valve prolapse in Marfan's syndrome. Circulation.1975;52:651-7. 
13. Woods SJ, Thomas J,Braimbridge MV.Mitral valve prolapse and open heart surgery in osteogenesis imperfect tarda .Br heart J.1973;35:103-6.

14.Grahame R, Edwards JC, Pticher D et al. A clinical and echocardiographic study of patients with hypermobility syndrome. Ann Rheum Dis, 1981;40:5416. 15. Pitcher D, Grahame R, MVP and joint hypermobility syndrome: evidence for connective tissue abnormality? Ann Rheum Dis;1982; 41:325-4

16. Camerota F,Castori M, Celletti C. Heart rate conduction and ultrasound abnormalities in adult with hypermobility syndrome .Clin Rheumatol,2014 Jul;33(7). 17. Cavenaghi S,Marino LH,Oliveira PP. Joint hypermobility in patients with mitral valve prolapse .Arq Bras Cardiol.2009(3):307-11.

18. Jessee EF, Owen DSJr, Sagar KB. The benign hypermobile joint syndrome. Arthritis Rheum 1980; 23:1053-6.
19. Mishra MB, Ryan $P$, Atkinson Pet al.Extraarticular features of benign joint hypermobility syndrome. $\mathrm{Br} \mathrm{J}$ Rheumatol,1996;35:861-6.

20. Perloff JK, Child JS and Edwards JE. New guidelines for the clinical diagnosis of MVP. J Cardiol,1986;57:1124-5.

21. Handler CE, Child A, Light ND,Dorrance DE. Mitral valve prolapses, aortic compliance and skin collagen in joint hypermobility syndrome. Br Heart J,1985;54:501-8.

22. Ondrasik M, Rybar I,Rus V, Bosak V. joint hypermobility in mitral valve prolapse patients. Clin Rheumatol,1988;17:69-73.

23. Marks JS, Sharp J,Brear SG,Edwards JD. Normal joint mobility in mitral valve prolapse patients. Ann Rheum Dis, 1983;42:54-5.

24. Riano F,Sanchez O, Pena N, Tineedoz. Joint hypermobility syndrome; a prospective study of articular and non- articular manifestation in a Venezuelan population. Rheumatol,2001;28:563-18. 